\title{
THE EFFECTS OF CARBONATED SOFT DRINKS ON SOME BIOCHEMICAL BLOOD PARAMETER AND LIVER HISTOPATHOLOGY OF EXPERIMENTAL RATS
}

\author{
SAMIA ALI AL-ASKALANY, MANAL MOHAMED SADEK AND NEVEN \\ MOHAMED MOHAMED
}

\author{
Special Food and Nutrition Dept., Food Technology Res. Instit. ARC, Giz, Egypt
}

(Manuscript received 3 July 2017)

\begin{abstract}
$\mathrm{C}$ arbonated soft drinks contain a multitude harmful substance; therefore, everyone should reduce their intake amounts. Beyond the fact that they have no nutritional value, these drinks can lead to long-term health problems. The present study estimated the effects of cola, orange, colorless and low calorie carbonated drinks, sucrose $10 \%$ and fructose $10 \%$ solutions on some biochemical blood parameters of experimental rats such as (triglycerides, cholesterol, LDL-C, vLDL-C, HDL-C, albumin, total protein, ALP, ALT and AST activity). Complete blood picture $\mathrm{CBC}$ (WBC, HGB, RBC, HCT, MCV, MCH, MCHC and PLT) and immunoglobulin bodies IgG and IgM were estimated. Histopathology examination of rat livers were also, checked. A 42 male rats were used and divided into seven groups each group contain 6 rats. The first group was the control and the other tested groups from G2 to G7 were intake cola, colorless, orange, low calorie soda drink, sucrose $10 \%$ solution and fructose $10 \%$ solution respectively. Each rate was intake $2.5 \mathrm{ml} \mathrm{w} / \mathrm{v}$ twice daily for 60 days by using stomach tube. The resulted data showed that there were significantly differences $(P<0.05)$ among all tested groups in blood parameters and blood picture in comparing with control group. Histopathology estimation, also, showed some effects on liver. It could be concluded that soda drinks had harmful effects on biochemical blood parameters and blood picture of the tested rats. The highest effects were in cola and low calories. The consumption for a long time different types of carbonated drinks might be contributing to the high prevalence of liver disease and may lead to a wide range of health problems.

Key words: biochemical analysis, histopathology, complete blood picture and immunoglobulin.
\end{abstract}

\section{INTRODUCTION}

Carbonated drinks are widely consumed because of their taste and ability to refresh and quench thirst. These carbonated drinks also exist in the form of diet drinks, for example Diet Coke, Pepsi, extra. In Europe, as well as, in Bulgaria, consumption of soft drinks and confectionery has increased during the last three decades and is partly responsible for increase obesity. These drinks, originally sweetened by sucrose, are now sweetened by other caloric sweeteners such as fructose (Sandeva et al., 2015). Today, High fructose corn syrup HFCS is almost 
exclusively used as a sweetener in the United States and high used in other countries because of its lower cost. Aspartame and caramel (colorant) are also used as sweeteners in the beverage industry mainly in diet soft drink (SD) (Ferland et al., 2007). Caramel is made by the carefully controlled heat treatment of carbohydrates, generally in the presence of acids and alkalis, in a process called caramelization. Soft drinks contain caramel coloring, which is rich in advanced glycation end products which increase insulin resistance and inflammation (Vlassara et al., 2002). Soft drinks are nonalcoholic water based flavored drinks that are optionally sweetened, acidulated, carbonated and may contain fruit, fruit juice and /or salts; their flavor may derive from vegetable extracts or other aromatic substances (Chandraker et al., 2014). Carbonated (and some non-carbonated) soft drinks contain a multitude harmful substances. The additives in soft drinks and sport drinks were found to have adverse effects. Both drinks are most favorable in summer season but regular usage may degrade the health. The carbonated soft drinks were found more toxic effects on health status (Das and Rajput 2013). The changing in food habits to suit modern living possesses a serious threat to gain a healthy life. Among others, consumption of soft drinks invariably forms a part of modern life. Consumption of soft drinks plays a major role in a variety of diseases, like obesity, diabetes, dental and bone disorders and others, more so among children and adolescents (Xavier, et al., 2007).

The objective of the current study is to investigate the effects of cola, orange, colorless and low calorie carbonated drinks, sucrose $10 \%$ and fructose $10 \%$ solutions on biochemical blood parameters and histopathology of liver of experimental animals. Most people used large amounts of carbonated drinks and one of the most global problems are the lack of awareness about the health issues associated with the excessive consumption.

\section{MATERIALS AND METHODS}

\section{Materials:}

Different types of carbonated drink (cola, orange, colorless and low calorie cola) and sucrose were bought from local market at Giza. Fructose was bought from El- Gomhoria Company, Cairo, Egypt.

\section{Methods:}

Sucrose solution: $10 \mathrm{~g}$ of sugars was dissolved in $100 \mathrm{ml}$ water.

Fructose solution: $10 \mathrm{~g}$ of fructose was dissolved in $100 \mathrm{ml}$ water.

\section{Biological experiment:}

The experiment was performed in the animal house of Ophthalmology, Giza, Egypt. Forty-two Sprague Dawley male rats (weighted 120 - $130 \mathrm{gm}$ ) were adapted 
by feeding on basal diet for one week before the initiation of the experiment. The compositions of the basal diet $(\mathrm{g} / 100 \mathrm{~g}$ diet) were consisted of $15 \mathrm{~g}$ casein, $1 \mathrm{~g}$ vitamin mixture, $4 \mathrm{~g}$ mineral mixture, $10 \mathrm{~g}$ corn oil, $5 \mathrm{~g}$ cellulose and $65 \mathrm{~g}$ starch (Tebib et al., 1997). The experimental rats were divided into 7 groups; each group contained 6 rats Group 1 (control) was fed on basal diet along the experiment period. The four groups 2, 3, 4 and 5 were fed on basal diet and four types of tested carbonated drinks (cola, orange, colorless and low calorie). Groups 6 and 7 were fed on basal diet and sucrose and fructose $10 \%$ solution. The tested rats groups were intake $2.5 \mathrm{ml} \mathrm{w} / \mathrm{v}$ twice daily by using stomach tube (Raj et al., 2009). The duration of experiments was 60 days after adaption one week. The blood samples were taken at the end of the experiment to monitor the effects of four types of carbonated drinks, as well as sucrose and fructose solutions in relative to the control and study the biochemical blood parameters and histopathology examination of liver.

\section{Blood samples preparation:}

Blood samples of experimental rats were taken from orbital plexus venous by using fine capillary tube. Blood samples were allowed to clot for $10 \mathrm{~min}$ at $37^{\circ} \mathrm{C}$ and centrifuged at $3000 \mathrm{CRF}$ for 5 minutes and then the separated serum was frozen and kept at $-18^{\circ} \mathrm{C}$ until assayed.

\section{Biological assays:}

Aspartate aminotransferase (AST), and Alanine aminotransferase (ALT), were colorimetrically estimated according to Reitman and Frankel (1957). Alkaline phosphatase (ALP) was determined according to Belfied and Goldberg (1971). A blood hemoglobin and hematocrit concentrations were measured according to Dacie and Lewis (2003). Complete blood cell count fractionated was performed on the EDTAtreated blood by using a Serono Baker Automated System (model 9000 Diff; Allentown, PA). Triglycerides, total cholesterol, LDL-C and VLDL-C were determined according to Fruchart (1982). HDL-c was determined according to Assman (1979). Total protein and albumin concentration was determined by the method of Doumas et al., (1971). The blood immunoglobulins (IgG and IgM) assays were measured according to Narayanans, (1982).

\section{Histopathology examination:}

Histopathology of liver was done at Institute of Ophthalmology, Giza, Egypt, using method of Drury and Wellington (1967). 


\section{Statistical analysis:}

Data Collected were subjected to the analysis of SAS, (2002) variance by using Duncan multiple range test procedure as described in the SAS software at significant level of $\mathrm{P}<0.05$.

\section{RESULTS AND DISCUSSION}

\section{Biochemical blood parameters:}

The effects of different types of carbonated soft drinks (cola, orange, colorless and low calories cola), sucrose and fructose solution on serum alkaline phosphatase ALP $(\mathrm{g} / \mathrm{dl})$, Aspartate Aminotransferase AST $(\mathrm{U} / \mathrm{L})$, Alanine Aminotransferase ALT $(\mathrm{U} / \mathrm{L})$ activity, total protein and albumin $(\mathrm{g} / \mathrm{dl})$ were recorded in Table (1). ALP showed no significant difference in orange and colorless soda drinks meanwhile, ALP increased in a significant difference in cola, low calorie, sucrose and fructose groups relative to control. The highest level ALP was found in sucrose $(70 \mathrm{~g} / \mathrm{dl})$ and fructose $(90 \mathrm{~g} / \mathrm{dl})$. Cola and low calories groups showed no significant difference $(P<0.05)$ between them but were significantly difference comparing with control.

The data showed a remarkable variation in serum ALT measurements in comparing with control. These variations have a high significant difference increasing in cola, orange and low calorie cola but the colorless one showed no significant difference $(P<0.05)$ with control. The highest level of ALT was in low calories soda (56 U/L), meanwhile lowest ALT was found in fructose solution group (29 U/L) in relative to control. There was also, no significant difference in cola and low calories cola between them, while sucrose solution group showed a significant difference increased (46.3 U/L) compared with control.

AST activities were increased significantly $(P<0.05)$ in cola, orange, colorless and low calories soda drink, meanwhile, were decreased in sucrose (25 U/L) and fructose $(24 \mathrm{U} / \mathrm{L})$ groups in relative to control. The data in present study cleared that decreased in a significant difference $(P<0.05)$ relative to control among sucrose and fructose groups in AST activities. The highest increasing in AST in a significant difference was in low calorie cola group relative to control.

Total proteins were significantly different increased in all groups except colorless soda group which resembles control in its value. Meanwhile cola, orange low calories and fructose groups showed no significant difference among them while, sucrose group $(3.7 \mathrm{~g} / \mathrm{dl})$ was the lowest one.

Albumin showed no significant difference $(P<0.05)$ in all groups in comparing with control and a slight increase was found in sucrose solution group. 
The data showed that cola, low calorie, sucrose and fructose were more effective on liver enzyme activity in a significant difference relative control. Meanwhile total protein was increased in, cola, low calorie, orange and fructose and decreased in sucrose groups. Albumin showed no significant difference $(P<0.05)$ comparing with control. These effects may be return to effect of sugars, acids, flavor, caramel and caffeine found in soda soft drink of these beverages. Such results agreed with Jeroh et al., (2012) who found that the consumption of carbonated drink may cause liver injury thereby increasing the liver enzyme activity (ALT and AST activity). The total protein, albumin and globulin were significantly difference $(P<0.05)$ and inversely related to type of soft drink intake. Raj et al., (2009) reported that ALT and ALP increased in serum rats fed on soft drink compared to control.

Table 1. ALT (U/L), AST $(\mathrm{U} / \mathrm{L})$ and ALP $(\mathrm{g} / \mathrm{dl})$ activities, total protein and albumin $(\mathrm{g} / \mathrm{dl})$ values of the tested rat serum.

\begin{tabular}{|c|c|c|c|c|c|}
\hline Groups type & ALP & ALT & AST & Total protein & Albumin \\
\hline Control & $46 \pm 0.57^{\mathrm{d}}$ & $40 \pm 1.15^{\mathrm{d}}$ & $33.33 \pm 0.88^{\mathrm{d}}$ & $4.63 \pm 0.08^{\mathrm{b}}$ & $3.33 \pm 0.08^{\mathrm{a}}$ \\
Cola & $54 \pm 0.57^{\mathrm{c}}$ & $53 \pm 1.15^{\mathrm{ab}}$ & $44.00 \pm 1.15^{\mathrm{b}}$ & $5.13 \pm 0.20^{\mathrm{a}}$ & $3.60 \pm 0.15^{\mathrm{a}}$ \\
Orange & $46 \pm 0.57^{\mathrm{d}}$ & $50 \pm 0.88^{\mathrm{b}}$ & $37.66 \pm 0.88^{\mathrm{c}}$ & $5.03 \pm 0.14^{\mathrm{a}}$ & $3.23 \pm 0.08^{\mathrm{a}}$ \\
Colorless soda & $47 \pm 1.45^{\mathrm{d}}$ & $40 \pm 0.58^{\mathrm{d}}$ & $42.00 \pm 1.15^{\mathrm{b}}$ & $4.63 \pm 0.08^{\mathrm{b}}$ & $3.33 \pm 0.08^{\mathrm{a}}$ \\
Low calories & $53 \pm 1.66^{\mathrm{c}}$ & $56 \pm 1.73^{\mathrm{a}}$ & $50.00 \pm 1.15^{\mathrm{a}}$ & $5.03 \pm 0.14^{\mathrm{a}}$ & $3.30 \pm 0.05^{\mathrm{a}}$ \\
Sucrose & $70 \pm 1.73^{\mathrm{b}}$ & $46.3 \pm 0.66^{\mathrm{c}}$ & $25.00 \pm 1.15^{\mathrm{e}}$ & $3.70 \pm 0.05^{\mathrm{c}}$ & $3.40 \pm 0.05^{\mathrm{a}}$ \\
Fructose & $90 \pm 1.15^{\mathrm{a}}$ & $29 \pm 1.15^{\mathrm{e}}$ & $24.00 \pm 1.15^{\mathrm{e}}$ & $5.40 \pm 0.00^{\mathrm{a}}$ & $3.30 \pm 0.17^{\mathrm{a}}$ \\
\hline
\end{tabular}

Each mean value, within the same column, followed by the same letter is not significantly different at 0.05 level. Each value, mean of three replicates, is followed by \pm standard deviation.

The data presented in Table (2) showed a significant increase in total cholesterol $(\mathrm{mg} / \mathrm{dl})$ level $(\mathrm{P}<0.05)$ in all groups compared with control. The maximum increasing was in the sucrose $(166 \mathrm{mg} / \mathrm{dl})$ and the low calories soda drink $(155 \mathrm{mg} / \mathrm{dl})$ groups. Meanwhile, the groups of cola, orange colorless soda drinks and fructose showed no significant difference $(P<0.05)$ among them and a slightly increased in significant difference relative to control. Moreover, the three soda drinks (cola, orange and colorless) and fructose solution revealed the same effects on total cholesterol in comparing with the low calories and sucrose groups.

Triglycerides $(\mathrm{mg} / \mathrm{dl})$ were increased in the significant difference $(P<0.05)$ in all groups comparing with control group, except colorless soda drink was showed no significant difference and decreased $(P<0.05)$ comparing with control. The highest level of triglycerides was in low calorie $(181 \mathrm{mg} / \mathrm{dl})$ and cola $(179 \mathrm{mg} / \mathrm{dl})$ soda drinks.

Data showed a slight decrease in HDL-c level and no significant difference in cola, colorless and fructose groups comparing with control. The low calorie soda drinks have the lowest decreasing in HDL-c level in significant difference in relative to control. Orange soda drink and sucrose were also, showed decreased a significant difference in HDL-c comparing with control. Raj et al., (2009) reported that HDL-C 
decreased in serum rats fed on soft drink. Meanwhile, cholesterol was moderately raised compared to control.

LDL-c level were increased significantly difference $(P<0.05)$ in cola, low calorie and sucrose groups (44.2, 78.06 and $80.9 \mathrm{mg} / \mathrm{dl}$, respectively). LDL-c in orange, colorless soft drink and fructose showed no significant difference in comparing with control. The highest increasing in LDL-C were in low calorie and sucrose groups relative to control.

Also, vLDL-c level was increased in significant difference $(P<0.05)$ in all groups except colorless soda drink which showed no significantly difference comparing to control. The highest increased in vLDL-c level was in low calorie group relative to control.

The data indicated that there were significant increases in total cholesterol, triglycerides; LDL-C and VLDL-C while there were decreasing in HDL-c. Leclercq and Horsmans (2008) stated that Carbonated drinks increased liver concentration of triglycerides (TG) and cholesterol esters. George et al., (2014) stated that the consumption of fructose solution in rats resulted increased body weight, blood glucose, total cholesterol and triglycerides compared to the control.

Immunoglobulin IgG were significantly decreased in all groups except colorless were no significant difference $(P<0.05)$ relative to control. The highest decreasing of IgG level was in cola, low calorie drinks and sucrose (58, 58.3 and 61.3 $\mathrm{mg} / \mathrm{dl}$, respectively) related to control.

Immunoglobulin IgM showed no significant differences in orange, colorless and fructose groups. While cola, low calories and sucrose showed a slight increase in a significant difference comparing with control. The present results showed that IgG was decreased and IgM slightly effects by carbonated drinks.

Table 2. Cholesterol fractions, Triglycerides, IgG and IgM in rat serum.

\begin{tabular}{|c|c|c|c|c|c|c|c|}
\hline Groups type & $\begin{array}{c}\text { Total } \\
\text { cholesterol } \\
\mathrm{mg} / \mathrm{dl}\end{array}$ & $\begin{array}{c}\text { Triglycerides } \\
\mathrm{mg} / \mathrm{dl}\end{array}$ & $\begin{array}{c}\text { HDL-c } \\
\mathrm{mg} / \mathrm{dl}\end{array}$ & $\begin{array}{c}\text { LDL-c } \\
\mathrm{mg} / \mathrm{dl}\end{array}$ & $\begin{array}{c}\mathrm{vLDL}-\mathrm{c} \\
\mathrm{mg} / \mathrm{dl}\end{array}$ & $\begin{array}{c}\mathrm{IgG} \\
\mathrm{mg} / \mathrm{dl}\end{array}$ & $\begin{array}{c}\text { IgM } \\
\mathrm{mg} / \mathrm{dl}\end{array}$ \\
\hline Control & $104 \pm 0.57^{\mathrm{d}}$ & $121 \pm 2.88^{\mathrm{d}}$ & $47 \pm 0.57^{\mathrm{a}}$ & $32.7 \pm 1.24^{\mathrm{c}}$ & $24.3 \pm 0.66^{\mathrm{d}}$ & $69.3 \pm 2.03^{\mathrm{a}}$ & $25,00 \pm 1.15^{\mathrm{c}}$ \\
Cola & $115 \pm 1.15^{\mathrm{c}}$ & $179 \pm 2.90^{\mathrm{a}}$ & $44 \pm 1.15^{\mathrm{ab}}$ & $44.2 \pm 2.50^{\mathrm{b}}$ & $34 \pm 0.57^{\mathrm{b}}$ & $58.0 \pm 2.08^{\mathrm{c}}$ & $27.83 \pm 1.18^{\mathrm{b}}$ \\
Orange & $113 \pm 1.14^{\mathrm{c}}$ & $170 \pm 2.88^{\mathrm{b}}$ & $42 \pm 2.33^{\mathrm{b}}$ & $37.0 \pm 1.00^{\mathrm{c}}$ & $35.9 \pm 0.58^{\mathrm{a}}$ & $65.3 \pm 2.90^{\mathrm{b}}$ & $25.36 \pm 1.55^{\mathrm{c}}$ \\
Colorless soda & $111 \pm 2.88^{\mathrm{c}}$ & $115 \pm 2.03^{\mathrm{d}}$ & $43 \pm 0.88^{\mathrm{ab}}$ & $34.7 \pm 1.46^{\mathrm{c}}$ & $23.1 \pm 0.41^{\mathrm{d}}$ & $67.3 \pm 2.33^{\mathrm{ab}}$ & $25.60 \pm 0.73^{\mathrm{c}}$ \\
Low calorie & $155 \pm 2.88^{\mathrm{b}}$ & $181 \pm 1.85^{\mathrm{a}}$ & $40 \pm 1.20^{\mathrm{b}}$ & $78.06 \pm 2.02^{\mathrm{a}}$ & $36.3 \pm 0.37^{\mathrm{a}}$ & $58.3 \pm 2.60^{\mathrm{c}}$ & $30.13 \pm 0.61^{\mathrm{a}}$ \\
Sucrose & $166 \pm 0.88^{\mathrm{a}}$ & $165 \pm 2.60^{\mathrm{bc}}$ & $42 \pm 1.15^{\mathrm{b}}$ & $80.9 \pm 1.57^{\mathrm{a}}$ & $33.1 \pm 0.52^{\mathrm{bc}}$ & $61.3 \pm 3.17^{\mathrm{bc}}$ & $28.86 \pm 1.71^{\mathrm{b}}$ \\
Fructose & $112 \pm 1.15^{\mathrm{c}}$ & $162 \pm 1.15^{\mathrm{c}}$ & $44 \pm 0.88^{\mathrm{ab}}$ & $35.0 \pm 1.73^{\mathrm{c}}$ & $32.4 \pm 0.23^{\mathrm{c}}$ & $64 \pm 1.15^{\mathrm{b}}$ & $25.63 \pm 0.26^{\mathrm{c}}$ \\
\hline
\end{tabular}

Each mean value, within the same column, followed by the same letter is not significantly different at 0.05 level. Each value, mean of three replicates, is followed by \pm standard deviation. 


\section{Effect of carbonated drinks on organs weight of rats:}

The data organs weights $(\mathrm{g})$ of the presented study were recorded in Table (3). There were no significant difference in livers weight between all groups and decrease significantly relative to control. On the other hand low calories soft drinks showed a significant decrease in liver weight at $(P<0.05)$ comparing with control.

Kidney weight was recorded an increased a significant difference $(P<0.05)$ in all groups comparing to control. The highest increasing in kidney weight were in cola $(2.23 \mathrm{~g})$ and sucrose $(2 \mathrm{~g})$ groups. The orange, colorless, soda drink and sucrose groups showed also, no significant difference $(P<0.05)$ in kidney weights between them.

Pancreas weight showed no significant difference $(P<0.05)$ with control. The results recorded a slightly increasing in pancreas weights in cola, orange, clear and low calories soda drink groups. The data also, recorded decreases in sucrose $(0.43 \mathrm{~g})$ and fructose $(0.50 \mathrm{~g})$ groups in pancreas weight.

Spleen showed decreasing and no significant difference $(P<0.05)$ in cola, orange, low calories soda drink and sucrose group relative to control. While colorless soda drink and sucrose showed the highest decreasing in spleen weight. Organs weight has slightly affected significantly by type soda drink and sucrose meanwhile fructose group more affected significantly $(P<0.05)$.

Table 3. Effect of carbonated drinks on weight organs of Liver, Kidney, pancreas and Spleen ( $\mathrm{g})$ :

\begin{tabular}{|c|c|c|c|c|}
\hline Groups type & Liver $(\mathrm{g})$ & Kidney $(\mathrm{g})$ & Pancreas $(\mathrm{g})$ & Spleen $(\mathrm{g})$ \\
\hline Control & $7.1 \pm 0.06^{\mathrm{a}}$ & $1.40 \pm 0.05^{\mathrm{d}}$ & $0.60 \pm 0.00^{\mathrm{bc}}$ & $1.43 \pm 0.08^{\mathrm{b}}$ \\
Cola & $6.4 \pm 0.14^{\mathrm{b}}$ & $2.23 \pm 0.14^{\mathrm{a}}$ & $0.70 \pm 0.05^{\mathrm{ab}}$ & $1.53 \pm 0.09^{\mathrm{ab}}$ \\
Orange & $6.0 \pm 0.06^{\mathrm{c}}$ & $1.80 \pm 0.11^{\mathrm{bc}}$ & $0.70 \pm 0.11^{\mathrm{ab}}$ & $1.33 \pm 0.03^{\mathrm{bc}}$ \\
Colorless & $6.5 \pm 0.20^{\mathrm{b}}$ & $1.73 \pm 0.08^{\mathrm{bc}}$ & $0.66 \pm 0.03^{\mathrm{ab}}$ & $1.16 \pm 0.13^{\mathrm{c}}$ \\
Low calories & $5.9 \pm 0.08^{\mathrm{c}}$ & $1.83 \pm 0.06^{\mathrm{bc}}$ & $0.76 \pm 0.06^{\mathrm{a}}$ & $1.33 \pm 0.03^{\mathrm{bc}}$ \\
Sucrose & $6.8 \pm 0.05^{\mathrm{ab}}$ & $2.00 \pm 0.12^{\mathrm{ab}}$ & $0.43 \pm 0.03^{\mathrm{c}}$ & $1.30 \pm 0.05^{\mathrm{bc}}$ \\
Fructose & $6.5 \pm 0.12^{\mathrm{b}}$ & $1.60 \pm 0.05^{\mathrm{cd}}$ & $0.50 \pm 0.05^{\mathrm{bc}}$ & $1.70 \pm 0.00^{\mathrm{a}}$ \\
\hline
\end{tabular}

Each mean value, within the same column, followed by the same letter is not significantly different at 0.05 level. Each value, mean of three replicates, is followed by \pm standard deviation.

\section{Complete blood picture and white blood cell fractions of tested rats blood:}

Complete blood picture data of rats, white blood cells (WBC), haemoglobin $H G B$, haematocrit $(H C T)$, red blood cells (RBC), mean corpuscular volume (MCV), mean corpuscular haemoglobin (MCH), mean corpuscular haemoglobin concentration (MCHC) and platelets (PLT) were indicated in Tables (4). The data were showed a decrease in significant differences $(P<0.05)$ in white blood cells WBC,s count in all tested groups relative to control. There were no significant difference in orange, 
colorless, low calorie, sucrose and fructose groups in WBC's among them. The highest decreasing WBC, s count were in cola and orange carbonated drinks.

Haemoglobin HGB concentration showed slightly decreased and no significant difference in colorless and low calorie groups compared with control. While the other tested groups showed a significant difference in HGB concentration relative control. Haematocrit HCT contents increased a significant difference in all groups relative control. The highest level of HCT was showed in sucrose.

Red blood cells RBC,s showed decreased a significant difference among groups and control. The lowest level of RBC,s count was showed in cola, low calorie and fructose groups.

Mean corpuscular volume (MCV) and mean corpuscular haemoglobin (MCH) showed increased and no a significant difference among tested groups and control. Mean corpuscular haemoglobin concentration (MCHC) a significant difference decreased among groups and control. Meanwhile, platelets (PLT) contents showed increased a significant difference in tested groups relative to control. The highest PLT contents were showed in sucrose and fructose. The results agreed with Arhan et al., (2011) who demonstrated that seed extract of Cola acuminata on the haematology of adult male albino rats showed no significant effect of on HCT of rats have been reported and the alterations noticed in the HCT value may be due to dehydration in the rats. The increase in the MCV values of the groups at the end of the experiment is indicative of macrocytosis which is associated with regenerative processes that may occur during tissue damage or heightened cellular activity. It was also; found that high MCV and MCH values are usually due to macrocytic anaemia, which most of the time result from vitamin deficiencies.

Table 4. Blood picture items (WBC, s, HGB, RBC, s, HCT, MCV, MCH, MCHC and PLT) in the tested rats blood:

\begin{tabular}{|c|c|c|c|c|c|c|c|c|}
\hline Groups type & $\begin{array}{l}\text { WBC } \\
10^{9} / \mathrm{ml}\end{array}$ & $\begin{array}{l}\text { HGB } \\
g / d l\end{array}$ & $\begin{array}{l}\text { HCT } \\
g / d l\end{array}$ & $\begin{array}{c}\mathrm{RBC} \\
10^{9 /} / \mathrm{ml} \\
\end{array}$ & $\begin{array}{c}\text { MCV } \\
\left(\mathrm{mm}^{3}\right) \text { per cell }\end{array}$ & $\begin{array}{c}\mathrm{MCH} \\
10^{-3 /} / \mathrm{ml} \\
\end{array}$ & $\begin{array}{l}\text { MCHC } \\
g / d l\end{array}$ & $\begin{array}{c}\text { PLT } \\
10^{9} / \mathrm{ml}\end{array}$ \\
\hline Control & $12.93 \pm 0.23^{\mathrm{a}}$ & $15.53 \pm 0.42^{\mathrm{a}}$ & $33.50 \pm 0.57^{d}$ & $7.80 \pm 0.58^{\mathrm{a}}$ & $52.43 \pm 0.52^{\mathrm{ab}}$ & $21.17 \pm 0,15^{a b}$ & $40.20 \pm 0.00^{a}$ & $505 \pm 2.8 g^{f}$ \\
\hline Cola & $7.80 \pm 0.11^{c}$ & $13.03 \pm 0.08^{e}$ & $38.00 \pm 0.28^{b}$ & $6.16 \pm 0.09 c$ & $54.00 \pm 0.57^{\mathrm{ab}}$ & $22.00 \pm 0.58^{\mathrm{a}}$ & $39.80 \pm 0.17^{\mathrm{ab}}$ & $578 \pm 2.65^{e}$ \\
\hline Orange & $7.43 \pm 0.78^{c}$ & $14.80 \pm 0.11^{\text {bcd }}$ & $38.00 \pm 0.51^{b}$ & $7.16 \pm 0.00^{8 \mathrm{bo}}$ & $52.00 \pm 1.15^{c}$ & $21.13 \pm 0.26^{\mathrm{ab}}$ & $39.80 \pm 0.17^{\mathrm{ab}}$ & $675 \pm 2.89^{c}$ \\
\hline Colorless & $9.33 \pm 0.33^{\mathrm{bc}}$ & $15.23 \pm 0.17^{\mathrm{bbc}}$ & $38.00 \pm 0.23^{b}$ & $7.32 \pm 0.01^{1 \mathrm{~b}}$ & $53.40 \pm 0.11^{\text {bc }}$ & $20.90 \pm 0.17^{\mathrm{b}}$ & $39.37 \pm 0.43^{\text {ab }}$ & $660 \pm 2.89^{d}$ \\
\hline Low calories & $8.56 \pm 0.24^{4 c}$ & $15.40 \pm 0.12^{\mathrm{ab}}$ & $36.60 \pm 0.05^{c}$ & $6.85 \pm 0.00^{\mathrm{cc}}$ & $52.80 \pm 0.17^{b c}$ & $20.83 \pm 0.21^{b}$ & $39.60 \pm 0.29^{\mathrm{ab}}$ & $683 \pm 5.77^{c}$ \\
\hline Sucrose & $8.46 \pm 0.41^{b c}$ & $14.40 \pm 0.05^{d}$ & $40.36 \pm 0.26^{\mathrm{a}}$ & $7.17 \pm 0.17^{7 \mathrm{~b}}$ & $54.83 \pm 0.32^{\mathrm{a}}$ & $21.30 \pm 0.06^{a b}$ & $38.90 \pm 0.17^{b}$ & $705 \pm 5.19^{b}$ \\
\hline Fructose & $10.00 \pm 1.15^{b}$ & $14.70 \pm 0.12^{c d}$ & $38.40 \pm 0.58^{b}$ & $6.80 \pm 0.00^{6 \mathrm{c}}$ & $54.83 \pm 0.20^{\mathrm{a}}$ & $21.50 \pm 0.17^{\mathrm{ab}}$ & $39.00 \pm 0.58^{b}$ & $794 \pm 5.77^{\mathrm{a}}$ \\
\hline
\end{tabular}

Each mean value, within the same column, followed by the same letter is not significantly different at 0.05 level. Each value, mean of three replicates, is followed by \pm standard deviation.

Differentiation of white blood cell fractions WBC,s (seg, staff, lymph, monocytes, and esosinophiles ) of tested rats were presented in Table (5). The data 
showed that seg. $\%$ was increased a significant difference $(P<0.05)$ in cola, orange, and sucrose meanwhile, decreased a significant difference among other tested groups compared to control. Moreover Staff. \% and Lymph. \%, showed decreased a significantly difference among tested groups and control.

Mono. \% was increased a significant difference in low calorie group carbonated drink and fructose group while decreased a significant difference in orange, colorless and sucrose groups relative to control. Esino. \% were decreased a significant difference in orange, low calorie and sucrose groups mainwhile, increased a significant difference in cola, colorless and fructose groups compared to control.

Table 5. Differentiation of WBC,s (Seg, Staff, Lymph, Mono and Esosinophiles \%) in the tested rat bloods:

\begin{tabular}{|c|c|c|c|c|c|}
\hline Groups type & Seg. \% & Staff. \% & Lymph.\% & Mono. \% & Esino \% \\
\hline Control & $38 \pm 0.57^{\text {cd }}$ & $13.00 \pm 1.15^{\mathrm{a}}$ & $48 \pm 1.15^{\mathrm{a}}$ & $7.00 \pm 1.15^{\mathrm{b}}$ & $4.00 \pm 0.57^{\mathrm{bc}}$ \\
Cola & $41 \pm 0.57^{\mathrm{c}}$ & $11.00 \pm 0.57^{\mathrm{abc}}$ & $36 \pm 0.57^{\mathrm{c}}$ & $7.00 \pm 0.57^{\mathrm{b}}$ & $5.00 \pm 0.00^{\mathrm{b}}$ \\
Orange & $53 \pm 0.88^{\mathrm{a}}$ & $9.33 \pm 0.88^{\mathrm{cd}}$ & $42 \pm 1.15^{\mathrm{b}}$ & $5 . .66 \pm 0.33^{\mathrm{b}}$ & $3.00 \pm 0.33 \mathrm{~b}^{\mathrm{c}}$ \\
colorless & $32 \pm 0.57^{\mathrm{e}}$ & $12.00 \pm 0.57^{\mathrm{ab}}$ & $46 \pm 0.57^{\mathrm{a}}$ & $5.66 \pm 0.33^{\mathrm{b}}$ & $5.00 \pm 0.57^{\mathrm{b}}$ \\
Low calories & $35 \pm 0.00^{\mathrm{de}}$ & $7.00 \pm 0.57^{\mathrm{d}}$ & $37 \pm 0.57^{\mathrm{c}}$ & $11.33 \pm 0.33^{\mathrm{a}}$ & $3.00 \pm 0.00^{\mathrm{c}}$ \\
Sucrose & $45 \pm 2.60^{\mathrm{b}}$ & $10.67 \pm 0.88^{\mathrm{abc}}$ & $38 \pm 1.17^{\mathrm{c}}$ & $5.66 \pm 0.33^{\mathrm{b}}$ & $3.33 \pm 0.33^{\mathrm{c}}$ \\
Fructose & $37 \pm 1.45^{\mathrm{cd}}$ & $10.00 \pm 0.57^{\mathrm{bc}}$ & $38 \pm 1.17^{\mathrm{c}}$ & $10.00 \pm 1.15^{\mathrm{a}}$ & $8.00 \pm 0.57^{\mathrm{a}}$ \\
\hline
\end{tabular}

Each mean value, within the same column, followed by the same letter is not significantly different at 0.05 level. Each value, mean of three replicates, is followed by \pm standard deviation.

\section{Histopathological examination of the tested rat liver:}

Histopathological examination of the tested rat liver presented in liver (Fig 1). The examination of tissue liver showed that group 1 was normal histological structure of hepatic lobule ( $H \& E X 400$ ), group 2 showing congestion of central vein and cytoplasmic vacuolization of hepatocytes (H \& E X 400), group 3 showing congestion of central vein and cytoplasmic vacuolization of hepatocytes (H \& E X 400), group 4 showing cytoplasmic vacuolization of hepatocytes and sinusoidal leucocytosis (H \& E X 400), group 5 showing cytoplasmic vacuolization of hepatocytes and cholangitis (H \& E X 400), group 6 showing hyperplasia of epithelial lining bile duct and fibroplasia in the portal triad (H \& E X 400) and group 7 showing cytoplasmic vacuolization of hepatocytes, congestion of hepatoportal blood vessel and fibroplasia in the portal triad (H \& E X 400). 
Fig. 1. Histopathological examination of liver organ of tested rat:

\begin{tabular}{|c|c|}
\hline \multicolumn{2}{|c|}{ liver } \\
\hline 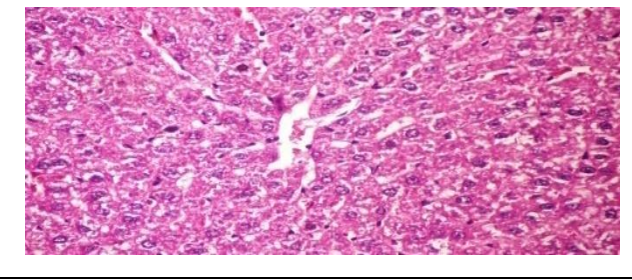 & 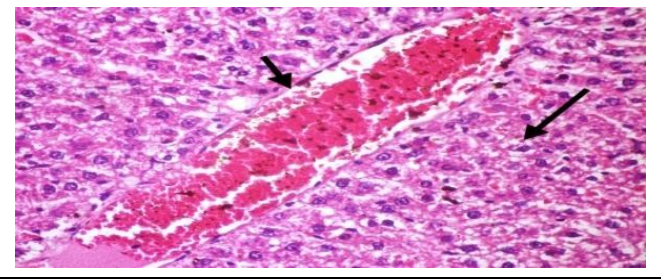 \\
\hline Group (1) & Group (2) \\
\hline 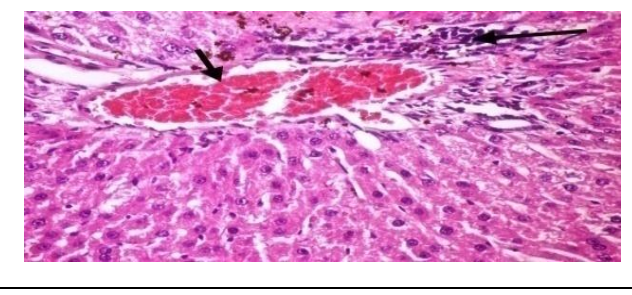 & 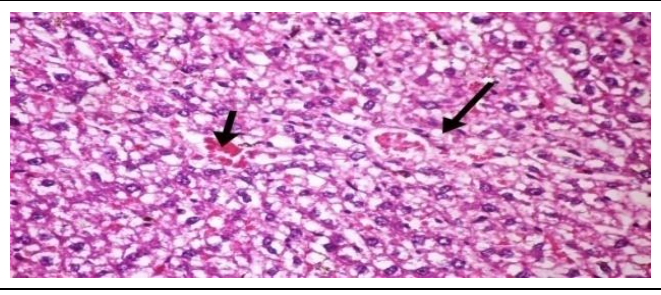 \\
\hline Group (3) & Group (4) \\
\hline 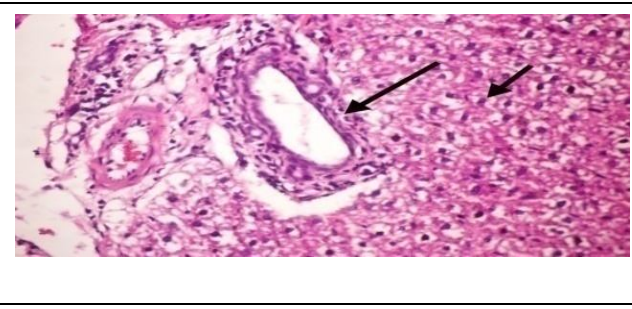 & 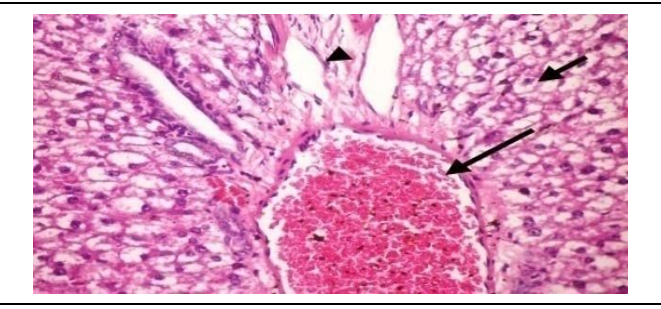 \\
\hline Group (5) & Group (6) \\
\hline 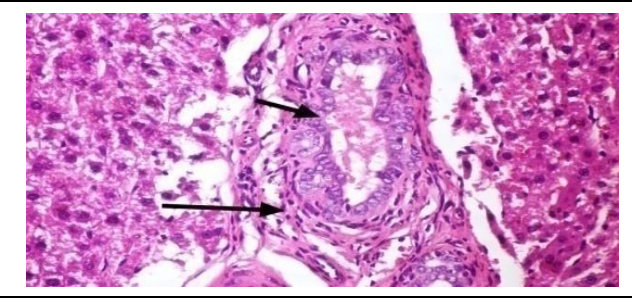 & \\
\hline Group (7) & \\
\hline
\end{tabular}

\section{CONCLUSION}

Soda drinks have no nutritional value and contain a multitude of chemical substance used in manufactures such as phosphoric acid, citric acid, flavors and colors. Also, it contain large amounts of sugars has been linked to a number of public health and medical effects. Moreover low calories soda drink contains aspartame which was lead to memory loss, dizziness and headache. The carbonated drinks should be reduce intake to anyone or stop drinking them because intake for a long time affects on blood parameters, liver and can lead to long-term of health problems. 


\section{REFERENCES}

1. Arhan, M. I. K.; Onal, A.; Tas, M.; Kurt, I. H.; Kalkan, Y.; Ozin, B.; Tun C. and Ulker, A. 2011. The role of red cell distribution width as a marker in inflammatory bowel disease. Turkish Journal of Medical Science, 41(2): 227-34.

2. Assman, G. 1979. A fully enzymatic colorimetric determination of HDL-cholesterol in serum. Internist., 20: 559-563.

3. Belfied, A. and Goldberg, D. M. 1971. Alkaline phosphatase calorimetric method. Enzyme, 12: 561-566.

4. Chandraker, S. K.; Singh P. and Pandey, B. 2014. Clastogenic effect of soft drink on root tip of Allium cepa. Int J Curr Microbiol App. Sci., 3(5): 200-206.

5. Dacie, J. V. and Lewis, S. M. 2003. Practical Hematology. A collaborative analysis of an improved procedure. Ninth Edition by M. LEWIS, B. J. BAIN, I. BATES, London: Churchill Livingstone and Carden Jennings Publishing Co., Ltd. Book Review.

6. Das, S. and Rajput, S. S. 2013. Toxic Level of Soft Drinks and Sport Drinks on Health Status. IJAPBC - Vol. 2(4):591-594.

7. Doumas, B. T.; Watson, W. A. and Biggs, H. C. 1971. Albumin standards and measurement of albumin with bromocresol green. Clin. Chem. Acta., 31:87-92.

8. Drury, R. A. Z. and Wellington, F. A. 1967. Carleton's histological technique $4^{\text {th }}$ ed. Oxford University Press, London.

9. Ferland, A.; Brassard, P. and Poirier, P. 2007. Is aspartame really safer in reducing the risk of hypoglycemia during exercise in patients with type 2 diabetes? Diabetes Care., 30; 59- 64.

10. Fruchart, J. C. 1982. Metabolism of lipoprotein at the cellular level relation to atherogensis. Clin. Chem., 27(5): 653-662.

11. George, A.; Bray, G. A. and Popkin, B. M. 2014. Dietary Sugar and Body Weight: Have We Reached a Crisis in the Epidemic of Obesity and Diabetes? Diabetes Care, : 37(4):950-956.

12. Jeroh, E.; Awhin, E. P.; Osademe, L. and Awire, E. I. 2012. Effect of Carbonated Drinks on The Activity of Alanine Aminotransferase (ALT) and Aspartate Aminotransferase (AST) in Serum and Kidney in Rattus Novergicus. Asian J. Biochemistry, 7 (1): 59-62.

13. Leclercq, I. A. and Horsmans, Y. 2008. Nonalcoholic fatty liver disease: the potential role of nutritional management. Curr. Opin. Clin. Nutr. Metab. Care; 11: 766-773. 
14. Narayanan, S. 1982. Method- comparison studies on immunoglobulins. Clin. Chem., 2: 1528-1531.

15. Raj, A.; Praveen, K. V.; Varghese, S.; Mukkadan, J. K. and Joseph, P. K. 2009. Biochemical effects of feeding soft drink and ethanol. Indian J. of Experimental Biology., 47: 333-337.

16. Reitman, S. and Frankel, S. 1957. A colorimetric method for the determination of serum glutamic oxaloacetic and glutamic pyrovic transaminase. Am. J. Clin. Path., 28:56-59.

17. Sandeva, R.V.; Mihaylova, M. S.; Sandeva, G. N.; Trifonova, K. Y.; PopovaKatsarova, R. D. 2015. Effect of High-Fructose Solution On Body Weight, Body Fat, Blood Glucose And Triglyceride Levels In Rats. J Biomed Clin, Res., 8 (1): 58.

18. SAS, 2002. Statistical Analysis System Proprietary software. Release 8.3. SAS Institute Inc., Carry, NC.

19. Vlassara, H.; Cai, W.; Crandall, J.; Goldberg, T.; Oberstein, R.; Dardaine, V.; Peppa, M. and Rayfield, E.J. 2002. Inflammatory mediators are induced by dietary glycotoxins, a major risk factor for diabetic angiopathy. Proc Natl. Acad. Sci. USA.,: 99: 15596-15601.

20. Xavier, R.; Sreeramanan, S.; Diwakar, A.; Sivagnanam G.and Sethuraman, K. R. 2007. Review Paper Soft Drinks and Hard Facts: A Health Perspective. ASEAN Food Journal, 14 (2): 69-81.

21. Tebib, K., j; Rouanet, M. and Besancon, P. 1997. Antioxidant effects of dietary polymeric grape seed tannins in tissues of rats fed a high cholesterol- vitamin Edeficient diet. Food Chemistry, 59(1): 135-141. 


\section{تأثير المشرويات الغازية على بعض المؤشرات البيوكيميائية

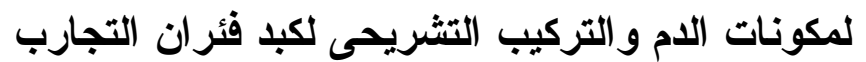
سامية على العقلاتى، منال محمد صادق، نيفين محمد محمد قسم بحوث الأغذية الخاصة والتغذية - معهد بحوث تكنولوجيا الاغذية- مركز البحوث الزراعيةجيزة دصر

تحتوى المشروبات الغازية على العديد من المواد التى تؤثز على الصحة على المدى البعيد

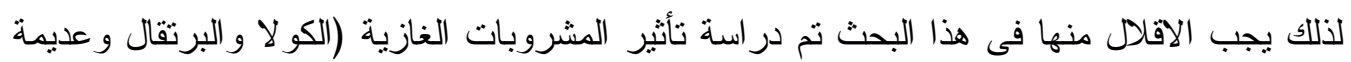

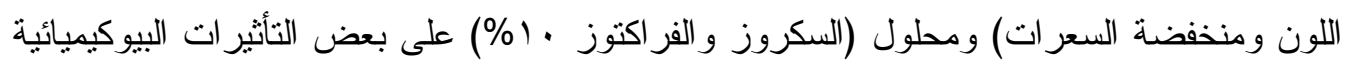
ومكونات الدم والخواص التشريحية في دم ذكور فئر ان التجارب منل الكولسترول و الجلسريدات

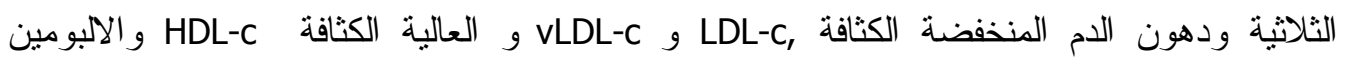
و البروتين الكلى ونشاط أنزيمات الكبد ALP و ALT و AST وجلوبيولينات المناعة و و IgG و و و وصورة الدم CBC و أستخدام عدد (Y (WBC, HGB, RBC, HCT, MCV, MCH, MCHC and PLT)

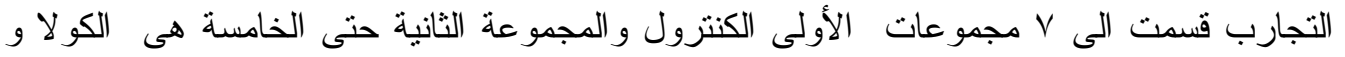
البرتقال وعديمة اللون و منخفضة السعرات من المياه الغازية و المجموعة السادسة محلول سكروز • 1\% و السابعة محلول فر اكتوز (1\% ،على الترتيب وذلك بأستخدام الانبوب المعوى بجرعات

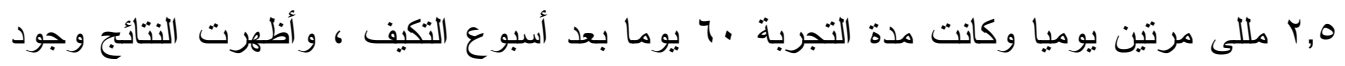

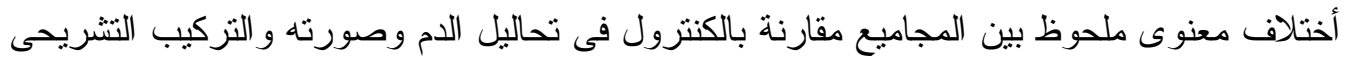
الذى أظهر بعض التأثير ات على الكبد.

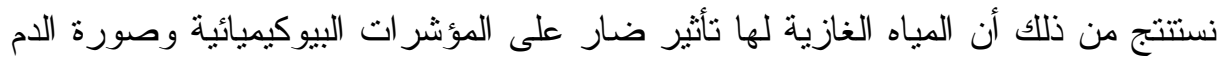

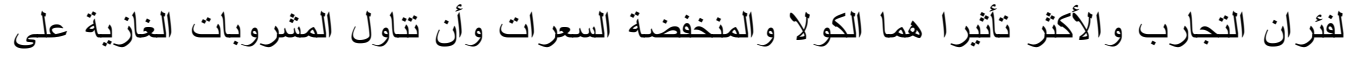

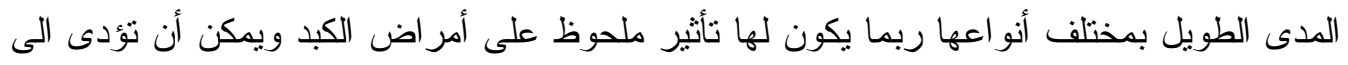

